\title{
The role of oocyte maturation inhibitor in follicular regulation of oocyte maturation
}

\author{
A. Tsafriri, N. Dekel and S. Bar-Ami
}

Department of Hormone Research, The Weizmann Institute of Science, Rehovot, 76100, Israel

Meiotic maturation of mammalian oocytes is a protracted process, subject to multiple stop-go controls (Text-fig. 1). The meiotic process is initiated during fetal life and is arrested shortly after birth at the stage of diplotene. Normally meiosis is resumed in adult life following the preovulatory surge of gonadotrophins (Ayalon, Tsafriri, Lindner, Cordova \& Harell, 1972; Vermeiden \& Zeilmaker, 1974; Tsafriri et al., 1976a; Dekel, Hillensjö \& Kraicer, 1979). Preovulatory resumption of meiosis includes the breakdown of the germinal vesicle (GVB), expulsion of the first polar body and the progress to the metaphase of the second meiotic division. Nevertheless, since GVB is the first change occurring and is widely used as an endpoint for assessing the resumption of meiosis, we shall refer to GVB as 'resumption of meiosis' or as 'oocyte maturation'.

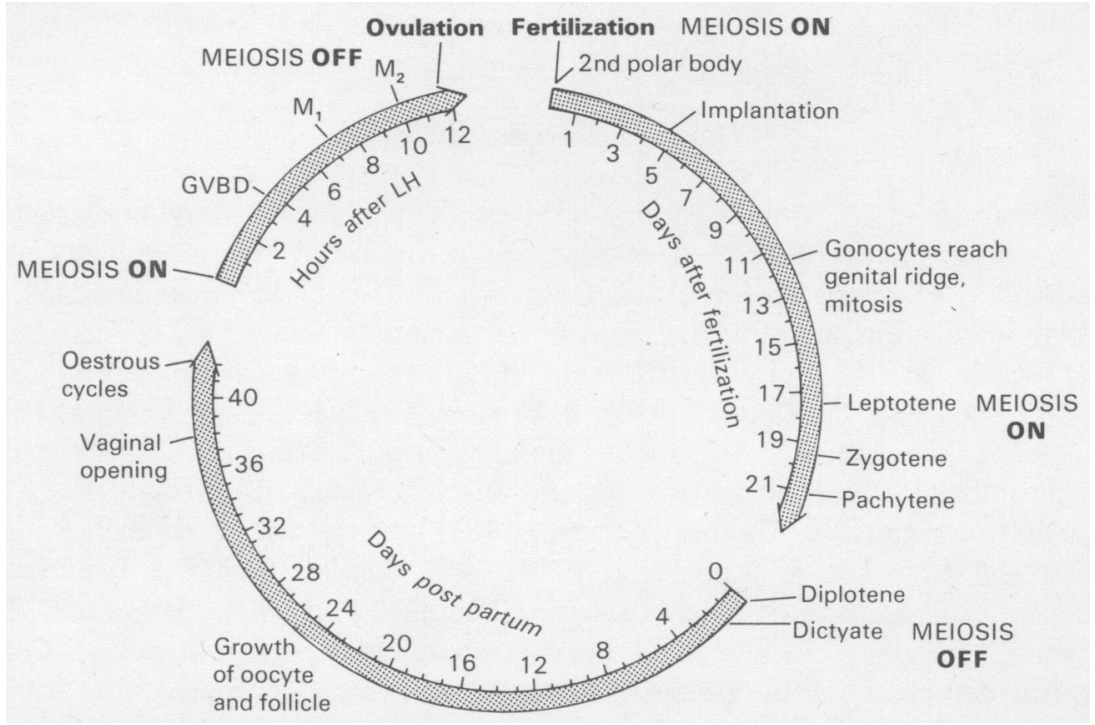

Text-fig. 1. Schematic presentation of multiple stop-go controls of oogenesis in the rat. (From Lindner, Bar-Ami \& Tsafriri, 1980.)

\section{Follicular control of oocyte maturation}

Resumption of meiosis in preovulatory follicles is dependent upon the preovulatory surge of gonadotrophins; abrogation of this surge prevents ovulatory changes, including maturation of the oocyte (Ayalon et al., 1972; Vermeiden \& Zeilmaker, 1974; Tsafriri et al., 1976a; Dekel et al., 1979). Similarly, in explanted follicle-enclosed oocytes the resumption of meiosis is 
dependent upon exposure of the follicles to gonadotrophins in vivo or in vitro (reviewed by Tsafriri, 1978; Moor \& Warnes, 1978; Baker, 1979). By contrast, Pincus \& Enzmann (1935) demonstrated that rabbit oocytes dislodged from their follicles undergo maturation in vitro even in hormone-free media. This observation has been confirmed and extended to many other mammalian species (reviewed by Biggers, 1972; Donahue, 1972; Schuetz, 1974). The spontaneous maturation of isolated oocytes prompted Pincus \& Enzmann (1935) to suggest that follicle cells in mammals "supply to the ovum a substance or substances which directly inhibit nuclear maturation". Chang (1955) was the first to demonstrate an inhibitory activity of follicular fluid upon spontaneous maturation of rabbit oocytes. Culture of porcine oocytes within hemisections of follicular wall prevented their spontaneous maturation, whereas oocytes cultured within the thecal tissue (Foot \& Thibault, 1969; Tsafriri \& Channing, 1975) or within the ovarian bursa (Leibfried \& First, 1980a) resumed meiosis. Co-culture of porcine oocytes with granulosa cells also inhibited the spontaneous resumption of meiosis (Tsafriri \& Channing, 1975; Sato \& Ishibashi, 1977), thus implicating the granulosa cells as the source of the follicular oocyte maturation inhibitor (OMI). This inhibitory effect depended on the number of granulosa cells cultured. In addition, cells from small follicles were more active in this respect as compared to cells from medium and large follicles. Similarly, when rat oocytes were added to rat granulosa cells previously cultured for 24 or $48 \mathrm{~h}$, resumption of maturation was suppressed and the degree of inhibition depended on the number of granulosa cells in the culture. The inhibitory effect of rat granulosa cells was reversed by the addition of $\mathrm{LH}(5 \mu \mathrm{g} / \mathrm{ml})$ to the cultures containing the oocytes (Tsafriri, 1979).

\section{Oocyte maturation inhibitor}

Spontaneous maturation of isolated porcine oocytes was also inhibited by an extract of porcine granulosa cells (Tsafriri, 1979) or by a 'conditioned' medium in which granulosa cells had been cultured previously (Tsafriri, Pomerantz \& Channing, 1976b; Centola, Anderson \& Channing, 1981). Oocyte maturation inhibiting activity was detected in follicular fluid collected from rabbit, sheep, cow, hamster and human ovaries (Chang, 1955; Tsafriri \& Channing, 1975; Gwatkin \& Andersen, 1976; Jagiello, Graffeo, Ducayen \& Prosser, 1977; Hillensjö, Kripner, Pomerantz \& Channing, 1979). This inhibition of oocyte maturation was not species specific; e.g. human follicular fluid inhibited the spontaneous maturation of porcine (Hillensjö et al., 1979) and rat (Hillensjö, Chari, Magnusson, Daume \& Sturm, 1981) oocytes, bovine follicular fluid inhibited hamster oocytes (Gwatkin \& Andersen, 1976), and porcine follicular fluid inhibited the maturation of mouse and rat oocytes (Tsafriri, Channing, Pomerantz \& Lindner, 1977). The OMI activity of porcine follicular fluid appears to decline during the course of follicular development as demonstrated by assays of follicular fluid freshly collected from small, medium and large follicles (Stone, Pomerantz, Schwartz-Kripner \& Channing, 1978) or fluid collected from pigs on specified days of their reproductive cycle (D. F. M. Van de Wiel, S. Bar-Ami \& A. Tsafriri, unpublished observations). In view of the low OMI activity of follicular fluid and especially the fact that the fluid from large follicles is devoid of this activity, it is not surprising that several investigators have failed to demonstrate an inhibitory action of follicular fluid (Sato \& Ishibashi, 1977; Leibfried \& First, 1980b). We have also found batches of follicular fluid which were inactive, but when the low molecular weight fraction was separated, it presented OMI activity.

By using porcine (Tsafriri \& Channing, 1975; Stone et al., 1978) or rat (Tsafriri et al., 1977) oocytes in culture as a bioassay system, porcine OMI has been partly characterized and purified. OMI is not extracted from porcine follicular fluid by ether or charcoal; it is heat stable (heating of the follicular fluid at $60^{\circ} \mathrm{C}$ for $20 \mathrm{~min}$, or of its low molecular weight fraction to $90^{\circ} \mathrm{C}$, did not destroy OMI activity) and its activity was abolished by treatment of the follicular fluid by 
trypsin (Tsafriri et al., 1976b; Tsafriri, Pomerantz \& Channing, 1976c). These results, taken together with evidence that OMI activity was eluted by gel-filtration in fractions corresponding to a molecular weight of less than 2000 , led to the conclusion that OMI is probably a peptide.

Currently, the following consecutive steps are being evaluated for OMI purification: filtration on Amicon membrane PM 10, methanol extraction, and Sephadex G-25 followed by CM-Sephadex chromatography (Table 1). After each step of purification, the recovery of OMI activity was estimated by testing the dose-response relation. One unit of OMI activity was defined as the amount of the inhibitor which blocked germinal vesicle breakdown by $50 \%$. Since $1 \mathrm{ml}$ follicular fluid exerted $50 \%$ inhibition of GVB (i.e. $0.001 \mathrm{U} / \mathrm{mg}$ peptide), an overall 5000 -fold purification of OMI was estimated on the basis of peptide determination. Recently the use of Sephadex G-10 instead of G-25 was explored. One peak of OMI activity was obtained (Text-fig. 2). Sephadex G-10 appears to be more useful than G-25 in giving one peak of activity while offering similar purification. This procedure supports the notion that OMI may be of even lower molecular weight than we originally assumed. OMI from porcine granulosa cell extract, and from 'conditioned' medium in which porcine granulosa cells were cultured previously, was chemically similar to OMI isolated from porcine follicular fluid (Centola et al., 1981).

Table 1. Purification of oocyte maturation inhibitor from porcine follicular fluid (from Lindner et al., 1980)

\begin{tabular}{lccccc}
\hline \multicolumn{1}{c}{ Fraction } & $\begin{array}{c}\text { Volume } \\
(\mathrm{ml})\end{array}$ & $\begin{array}{c}\text { Peptide* } \\
(\mathrm{mg} / \mathrm{ml})\end{array}$ & Units/mg & $\begin{array}{l}\text { Total } \\
\text { units }\end{array}$ & $\begin{array}{c}\text { Purification } \\
(\times) \dagger\end{array}$ \\
\hline Follicular fluid & 900 & 2000 & $0.001 \ddagger$ & $1800 \ddagger$ & - \\
Amicon PM-10 filtrate & $24 \cdot 5$ & 105 & 0.48 & 1225 & 480 \\
Sephadex G-25 peak A & 20 & 43.4 & 1.38 & 1200 & 1380 \\
CM-Sephadex active peak & 15 & 29 & 5.17 & $2250 \S$ & 5170 \\
\hline
\end{tabular}

* Based on peptide determination by the fluorescamine method (Udenfriend et al., 1972).

$\dagger$ Based on the estimated activity of follicular fluid.

$\ddagger$ Estimated, $1: 1$ dilution inhibited maturation by approximately $50 \%$.

$\S$ The observed increase in activity is probably due to removal of a stimulatory or facilitatory substance by purification.



Text-fig. 2. Purification of OMI by Sephadex G-10 chromatography. The methanol extract of the low molecular weight fraction of porcine follicular fluid $(320 \mathrm{mg}$ peptide) was applied to a column $(1.5 \times 65 \mathrm{~cm})$ of Sephadex G-10 and eluted with $0.5 \mathrm{M}$-acetic acid. (From Tsafriri \& Bar-Ami, 1981.)

\section{Physiological considerations of OMI action}

\section{Reversibility of OMI action}

Inhibition of the resumption of meiosis by OMI is reversible. This was demonstrated by transferring porcine oocytes after a $24 \mathrm{~h}$ culture with OMI to an inhibitor-free medium (Stone $e t$ 
al., 1978; Hillensjö et al., 1979). OMI activity was also prevented by the addition of an antiserum prepared against the low molecular weight fraction of porcine follicular fluid (Tsafriri et al., 1979).

\section{Induction of meiosis by $\mathrm{LH}$}

Resumption of meiosis in vivo is triggered by LH. The finding that the addition of $\mathrm{LH}$ overcomes the inhibition of meiosis in the presence of follicular fluid or of its purified fractions (Tsafriri et al., 1976b, c; Gwatkin \& Andersen, 1976) supports the view that OMI has a physiological role in the control of ovum maturation.

The inhibition of maturation of rat oocytes by porcine follicular fluid, its low molecular weight fraction and of a 'conditioned' medium were also reversed by LH. In Text-fig. 3 the time-course of the reversal of inhibition of the low molecular weight fraction of porcine follicular fluid is described. We showed that GVB was completed within $2 \mathrm{~h}$ in isolated rat oocytes cultured without the inhibitor, and that a culture period of $4 \mathrm{~h}$ was adequate for this change to occur in follicle-enclosed oocytes exposed to LH (Tsafriri, 1979). By contrast, addition of LH to isolated oocytes cultured with the low molecular weight fraction of folicular fluid resulted in GVB, in a number of oocytes comparable to that of control cultures, only after more than $10 \mathrm{~h}$ of incubation (Text-fig. 3), while in co-cultures with granulosa cells, LH induced GVB within $6 \mathrm{~h}$ (Tsafriri, 1978). The discrepancy in timing of GVB in these two experiments may be explained by considering the distribution of the receptors of $\mathrm{LH}$. So far, no specific $\mathrm{LH} / \mathrm{hCG}$ receptors on the oocytes have been detected. However, specific $\mathrm{LH} / \mathrm{hCG}$ receptors do occur on the cumulus cells (Amsterdam \& Tsafriri, 1979; Channing, Stone, Fowler, Edelson \& Schwartz-Kripner, 1979; Lawrence, Dekel \& Beers, 1980), as well as the granulosa cells. Nevertheless, the number of $\mathrm{LH}$ receptors per cumulus cell appears to be much smaller than the number per cell for mural granulosa cells. By considering the sensitivity of the method employed (Lawrence et al., 1980), it appears that the oocyte binds less than $1 \%$ of the label bound to a unit membrane area of cumulus cells. Therefore, it seems that the effect of $\mathrm{LH}$ on ovum maturation is not exerted directly, but through the mediation of granulosa and cumulus cells. The delay in GVB observed in response to LH in the presence of OMI, but not of granulosa cells, may be due to the inability of the cumulus cells included in the culture to act as substitutes for the granulosa cells. This inability might result from the low number of cumulus cells included in the culture or from the lower ability of cumulus cells to bind LH and hence to respond to the hormone.

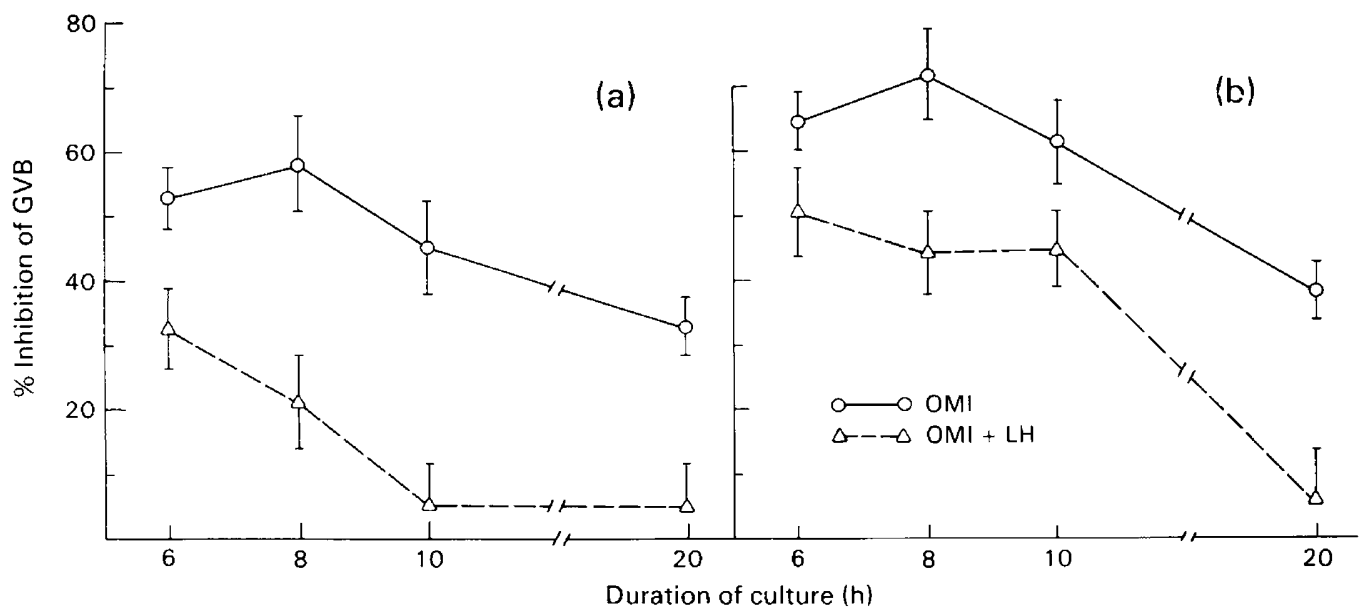

Text-fig. 3. Effect of OMI and LH on germinal vesicle breakdown (GVB) of rat oocytes in culture. Oocytes were cultured for $6 \mathrm{~h}$ with $85 \mu \mathrm{g}$ protein $/ \mathrm{ml} \mathrm{(a)} \mathrm{or} 170 \mu \mathrm{g} / \mathrm{ml}$ (b) of the low molecular weight fraction of porcine fluid. Values are mean \pm s.e.m. for $4-6$ groups each containing 15-20 oocytes. (From Tsafriri et al., 1977.) 


\section{Other factors involved in resumption of meiosis}

\section{Role of steroids}

The preovulatory surge of gonadotrophins induces a prompt rise in follicular steroidogenesis (reviewed by Lindner et al., 1974; Channing \& Tsafriri, 1977). However, addition of steroids to the culture medium did not induce the resumption of meiosis in follicle-enclosed oocytes. Furthermore, the inhibition of the LH-induced rise in steroidogenesis did not block the action of LH on nuclear maturation of rat oocytes (Text-fig. 4). It was therefore concluded that the action of $\mathrm{LH}$ on the resumption of meiosis is not mediated by its effect on follicular steroidogenesis. On the other hand, in cultured ovine follicle-enclosed oocytes, inhibition of steroidogenesis does not prevent the LH-induced resumption of meiosis but does block it at the metaphase I stage. Addition of oestradiol to such cultures, together with the gonadotrophin, prevented this block at metaphase I and improved fertilizability of the oocytes and their subsequent embryonic development after transfer to foster ewes (Moor \& Warnes, 1978). Also, the ability of oocytes to undergo spontaneous maturation in culture was recently shown to depend upon exposure to FSH, and the action of FSH appears to be mediated by follicular synthesis of oestradiol (Bar-Ami \& Tsafriri, 1981). Thus, despite the finding that steroids do not appear to mediate the meiosis-inducing action of gonadotrophin, they may have an important role in the development of the ability to resume meiosis and complete the process by reaching the metaphase II stage.

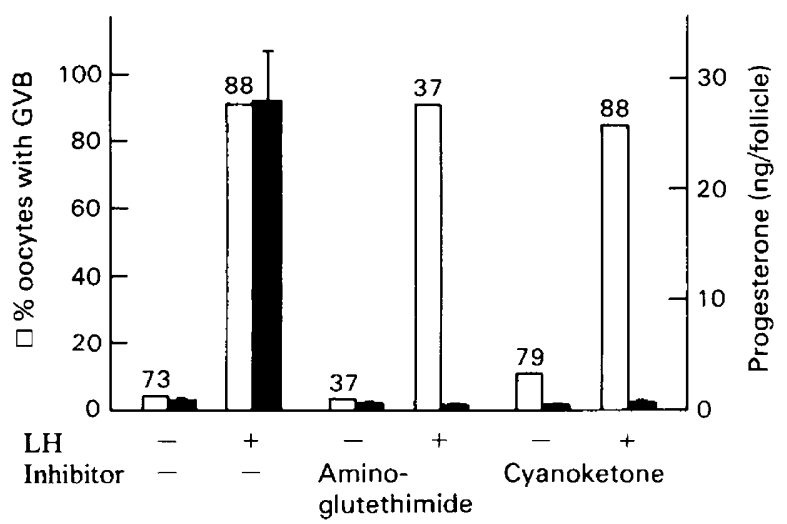

Text-fig. 4. Dissociation of the meiosis-inducing action of LH from the steroidogenic action of the hormone. Follicles were explanted on the morning of the day of pro-oestrus (before the endogenous surge of gonadotrophins) and cultured for $6 \mathrm{~h}$ with or without $\mathrm{LH}(5 \mu \mathrm{g} / \mathrm{ml})$, aminoglutethimide $\left(10^{-2} \mathrm{M}\right)$ or cyanoketone $\left(10^{-4} \mathrm{M}\right)$ as indicated. Progesterone accumulation in the medium was measured by radioimmunoassay; values are mean \pm s.e.m. for 5-9 determinations. GVB, germinal vesicle breakdown; the no. of oocytes examined for each treatment is indicated. (From Lindner et al., 1974.)

\section{Involvement of cumulus cell-oocyte communication}

OMI inhibited the resumption of meiosis only in oocytes cultured within their intact cumuli, but failed to affect the maturation of denuded porcine (Hillensjö et al., 1979) or rat oocytes (Text-fig. 5). It appears, therefore, that the inhibitory signal is communicated to the oocyte via the cumulus cells.

The close association between the cumulus cell and the oocyte was first described by Paladino (1890). Gap junctions between cumulus cell projections and the oocyte have been observed (Amsterdam, Josephs, Lieberman \& Lindner, 1976; Anderson \& Albertini, 1976; Gilula, Epstein \& Beers, 1978) and transfer of ions and small molecules between the oocyte and cumulus cells was demonstrated (Gilula, Epstein \& Beers, 1978; Moor, Smith \& Dawson, 


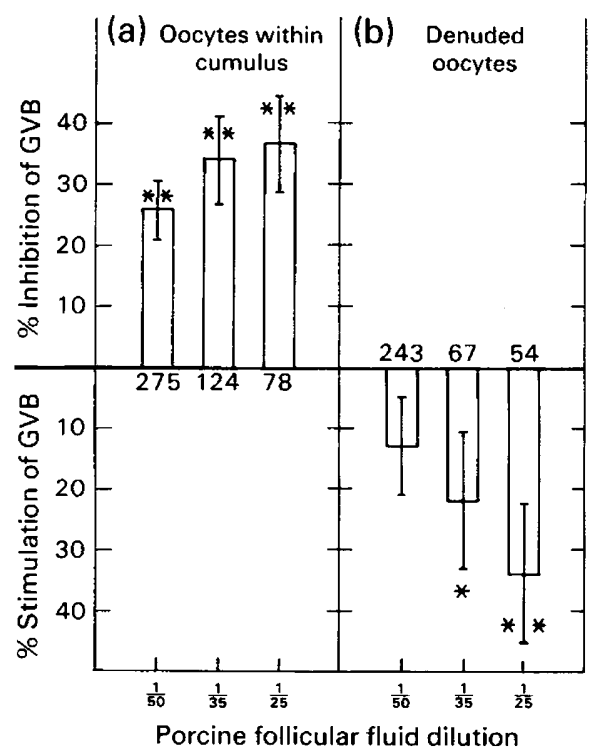

Text-fig. 4. Role of the cumulus cells in OMI action upon maturation of rat oocytes. Oocytes were cultures within their cumulus (a) or after removal of adherent cells by repeated transfers through thin-bore glass capillaries (b). Culture was for $6 \mathrm{~h}$ in the presence of the indicated dilution of the low molecular weight fraction of porcine follicular fluid. Values are mean \pm s.e.m. ${ }^{*} P<0.05{ }^{* *} P<0.005$ compared with appropriate control cultured without follicular fluid. (From Lindner et al., 1980.)

1980). Ionic coupling and transfer of molecules were maximal before gonadotrophic stimulation and decreased afterwards. This led to the hypothesis that the release of the oocyte from suppression of meiosis is a result of the dismantling or of functional disengagement of oocytecumulus cell junctions, possibly induced by the ovulatory hormone (Lindner et al., 1974; Dekel \& Beers, 1978; Gilula et al., 1978; Moor et al., 1980). Thus, the action of LH in meiotic maturation may be secondary to its action on the sequestration of the oocyte. However, the temporal sequence of meiotic changes and the breakdown of the oocyte-cumulus cell association poses a major difficulty for this hypothesis: the disruption of oocyte-cumulus cell communication follows rather than precedes germinal vesicle breakdown as demonstrated by the reduction of the transport of choline to sheep oocytes (Moor et al., 1980) and by the termination

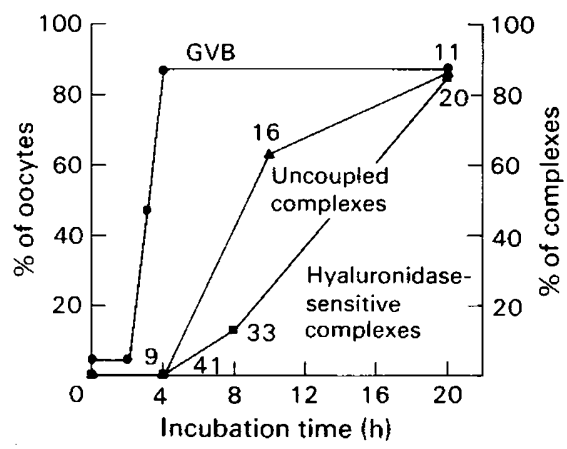

Text-fig. 6. The temporal changes in rat oocytes of ionic coupling, sensitivity to hyaluronidase and GVB. Follicles were incubated in the presence or absence of $10 \mu \mathrm{g} \mathrm{LH} / \mathrm{ml}$. The cumulusoocyte complexes were isolated at the times indicated and analysed for ionic coupling, sensitivity to hyaluronidase (no. indicated), and for the presence or absence of the germinal vesicle (4 different experiments). (From Dekel et al., 1981.) 
of ionic cumulus cell-oocyte coupling in the rat (Text-fig. 6). Moor, Osborn, Crun \& Walters (1981), using low levels of LH and FSH, have dissociated the disruption of cumulus cell-oocyte communication and the resumption of meiosis in ovine oocytes; FSH suppressed intercellular coupling without inducing meiosis. Conversely, LH induced meiotic maturation without affecting cumulus cell-oocyte coupling as reflected by choline transport. While it appears that the cumulus cells and their junctional associations with the oocyte are essential for the maintenance of meiotic arrest, it is not clear whether the disruption of cumulus cell-oocyte communication by itself is the physiological trigger for the resumption of meiosis. Transfer of choline or ions from the cumulus to the oocyte does not necessarily reflect the transport of the inhibitory signal. It is possible that transfer of the inhibitory signal is modified before the detection of changes in the transfer of choline or ions.

\section{Role of cyclic AMP}

The most prominent feature of the agents inducing the maturation of follicle-enclosed oocytes in vitro is their ability to stimulate production of cyclic AMP (cAMP) (Tsafriri, Lindner, Zor \& Lamprecht, 1972; Lindner et al., 1974). Injection of the cAMP derivative dibutyryl cAMP (dbcAMP) into the follicular antrum or short-term exposure of follicles to a medium containing 8-bromo-cAMP (Hillensjö, Ekholm \& Ahrén, 1978), dbcAMP or isobutyl methyl xanthine (IBMX) (Table 2) triggered GVB. However, the continuous presence of cAMP derivatives or of most of the phosphodiesterase inhibitors prevented the LH-induced maturation of follicle-enclosed oocytes (Lindner et al., 1974; Hillensjö et al., 1978; Dekel, Lawrence, Gilula \& Beers, 1981). Moreover, when isolated oocytes of mice and rats were cultured in the presence of cAMP derivatives or phosphodiesterase inhibitors, the spontaneous maturation of oocytes was prevented (Cho, Stern \& Biggers, 1974; Nekola \& Moore-Smith, 1975; Hillensjö, 1977; Hillensjö et al., 1978; Dekel \& Beers, 1978). It therefore appears that at the level of the oocyte, cAMP inhibits, rather than induces, the resumption of meiosis. If cAMP is involved in the mediation of the meiosis-inducing action of $\mathrm{LH}$, as the experiments with follicle-enclosed oocytes seem to indicate, then this effect is exerted through the mediation of other cells of the follicle. In



Text-fig. 7. Effect of cholera enterotoxin and LH on germinal vesicle (GV) breakdown in rat oocytes (no. as indicated at each point) in culture. Isolated cumulus-oocyte complexes were incubated for $24 \mathrm{~h}$ in the presence of the indicated concentration of cholera enterotoxin and $0.02 \mathrm{mM}-\mathrm{IBMX}$ with $(\square)$ or without $(0) \mathrm{LH}(10 \mu \mathrm{g} / \mathrm{ml})$. Denuded oocytes $(\Delta)$ were incubated in the presence of toxin and IBMX only. (From Dekel \& Beers, 1980.) 
the amphibian oocyte it was demonstrated that maturation induced by progesterone is associated with a transient decrease in the level of cAMP in the oocyte and protein phosphorylationdephosphorylation reaction (Speaker \& Butcher, 1977; Morrill, Schatz, Kostellow \& Poupko, 1977; Schorderet-Slatkine, Schorderet, Boquet, Godeau \& Baulieu, 1978; Maller, Butcher \& Krebs, 1979).

It was suggested that cAMP serves as the physiological inhibitor of meiosis which is transmitted from the cumulus cells via gap junctions (Lindner et al., 1974; Dekel \& Beers, 1978; Moor et al., 1980; Dekel et al., 1981). The adenylate cyclase activator, cholera enterotoxin (Cuatrecasas, Hollenberg, Chang \& Bennet, 1975), inhibits spontaneous maturation in oocytes, cultured within the cumulus but not in denuded oocytes (Text-fig. 7). This may suggest that cAMP produced by the cumulus cells is transferred to the oocytes and blocks the resumption of meiosis. The effect of $\mathrm{LH}$, which partly relieves this inhibitory effect, is probably due to its effect on breakdown of communication and hence block of transfer of cAMP to the oocyte. That LH, IBMX and dbcAMP bring about breakdown of the cumulus cell-oocyte communication is seen in Table 2. The action of short exposure to IBMX or dbcAMP (Table 3) may be interpreted as a result of communication breakdown. While it is questionable whether breakdown of communication between the cumulus cells and the oocyte is in itself a trigger for the resumption of meiosis, transfer of an inhibitory signal to the oocyte, most probably through the gap junctions, is required for maintaining meiotic arrest. Whether cAMP or OMI or both of these serve as the inhibitory signal at the level of the oocyte remains to be elucidated.

Table 2. Effect of LH and cAMP on intercellular communication in the cumulus cell-oocyte complex

\begin{tabular}{clcc}
\hline $\begin{array}{c}\text { Time in } \\
\text { culture }(\mathrm{h})\end{array}$ & Medium & $\begin{array}{c}\text { Total no. of } \\
\text { complexes examined }\end{array}$ & $\begin{array}{c}\text { \% of coupled } \\
\text { complexes }\end{array}$ \\
\hline \multirow{2}{*}{4} & Control & 5 & 100 \\
& LH & 9 & 100 \\
0 & Control & 7 & 100 \\
20 & LH & 16 & 37.5 \\
& Control & 16 & 100 \\
& LH & 11 & 0 \\
& IBMX & 11 & 0 \\
& dbcAMP & 5 & 0 \\
\hline
\end{tabular}

Follicles were incubated in the presence or absence of $\mathrm{LH}(10 \mu \mathrm{g} / \mathrm{ml})$, IBMX ( $0.2 \mathrm{mM})$ or dbcAMP ( $5 \mathrm{mM})$. Ionic coupling was recorded in the complexes recovered from these follicles after the indicated periods of incubation. (Data from Dekel et al., 1981.)

Table 3. Effect of dbcAMP and IBMX on the maturation of follicle-enclosed oocytes

\begin{tabular}{llcc}
\hline $\begin{array}{c}\text { Preincubation } \\
\text { medium }\end{array}$ & $\begin{array}{c}\text { Incubation } \\
\text { medium }\end{array}$ & $\begin{array}{c}\text { Total no. } \\
\text { of oocytes }\end{array}$ & $\begin{array}{c}\text { \% of oocytes } \\
\text { with GV }\end{array}$ \\
\hline Control & Control & 30 & 83 \\
IBMX & IBMX & 35 & 91 \\
IBMX & Control & 43 & 2 \\
dbcAMP & dbcAMP & 13 & 100 \\
dbcAMP & Control & 43 & 19 \\
\hline
\end{tabular}

Follicles were incubated in control medium, IBMX $(0.2 \mathrm{mM})$ or dbcAMP (5 mM). After $20 \mathrm{~h}$ the follicles were rinsed and transferred for further incubation in either the same medium or control medium. After $4 \mathrm{~h}$ of incubation, cumulus cell-oocyte complexes were isolated and the oocytes were examined for the presence of a germinal vesicle (GV). (Data from Dekel et al., 1981.) 


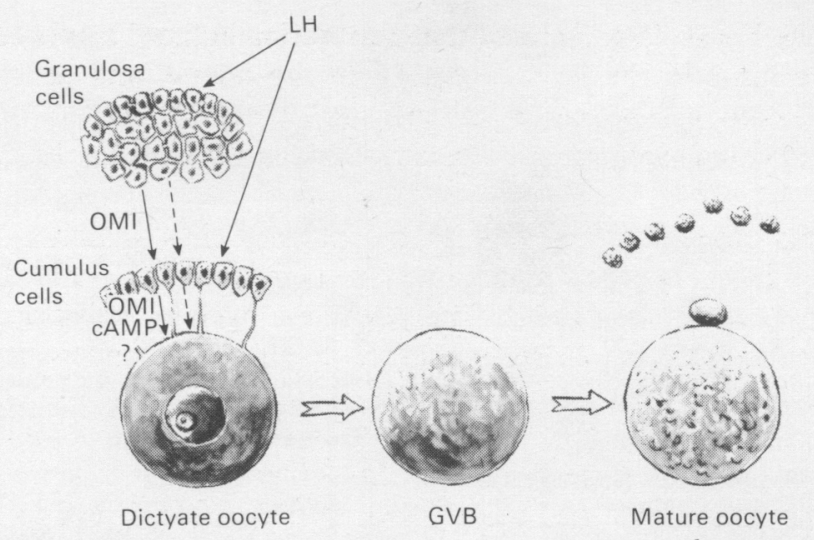

Text-fig. 8. Schematic representation of the control of meiotic maturation in mammalian oocytes. See text for explanation. (From Tsafriri \& Bar-Ami, 1981.)

\section{Conclusions}

Pincus \& Enzmann (1935) suggested that meiotic maturation in mammals is held in abeyance by a follicular factor. Recently, OMI from procine follicular fluid and granulosa cells was partly purified and characterized. However, OMI is only one of the factors involved in the control of the meiotic process. Other factors, such as oocyte-cumulus cell communication, cyclic AMP and steroids are probably involved in controlling meiosis. Some of the putative mechanisms involved in the control of meiosis are depicted schematically in Text-fig. 8. Meiosis is prevented in antral follicles by OMI produced by granulosa cells. The inhibitory action of OMI is apparently exerted through the mediation of cumulus cells and the signal conveyed through cumulus cell-oocyte gap junctions. It is not known whether cAMP or OMI are transferred to the oocyte as the inhibitory signal. LH induces the resumption of meiosis, possibly through the mediation of mural granulosa and cumulus cells. The mode of action of LH in inducing meiosis remains to be elucidated: LH may act either by eliminating the inhibitory signal, by blocking its transfer via the cumulus cell-oocyte junctions or by terminating OMI production. Alternatively, LH may generate a yet unspecified positive signal. More studies are needed to understand the intricate mechanism involved in the control of meiotic maturation. Purification of OMI to homogeneity is required for assessing the precise physiological role of this factor in the meiotic process.

Our studies reviewed here were supported by generous grants from the United States-Israel Binational Agricultural Research and Development Fund (BARD). The generous supply of part of the porcine follicular fluid by the Center for Population Research, NICHD, NIH, and of LH by NIAMDD, is gratefully acknowledged. We thank Mrs R. Davidov, Mrs A. Tsafriri and Ms J. Pesek for skilful technical assistance and Mrs M. Kopelowitz for excellent secretarial help.

\section{References}

Amsterdam, A. \& Tsafriri, A. (1979) In vitro binding of ${ }^{125}$ I-human chorionic gonadotrophin in the preovulatory follicle: absence of receptor sites on oocyte. J. Cell Biol. 83, 255A.

Amsterdam, A., Josephs, R., Lieberman, M.E. \& Lindner, H.R. (1976) Organization of intramem- brane particles in freeze-cleaved gap junctions of rat Graafian follicles: optical-diffraction analysis. J. Cell. Sci. 21, 93-105.

Anderson, E. \& Albertini, D.F. (1976) Gap junction between the oocyte and companion follicle cells in the mammalian ovary. J. Cell Biol. 71, 680-686. 
Ayalon, D., Tsafriri, A., Lindner, H.R., Cordova, T. \& Harell, A. (1972) Serum gonadotrophin levels in pro-oestrous rats in relation to the resumption of meiosis by the oocytes. J. Reprod. Fert. 31, 51-58.

Baker, T. G. (1979) The control of oogenesis in mammals. In Ovarian Follicular Development and Function, pp. 353-364. Eds A. R. Midgley \& W. A. Sadler. Raven Press, New York.

Bar-Ami, S. \& Tsafriri, A. (1981) The acquisition of meiotic competence in the rat: role of gonadotropin and estrogen. Gamete Res. 4, 463-472.

Biggers, J.F. (1972) Metabolism of the oocyte. In Oogenesis, pp. 241-251. Eds J. D. Biggers \& A. W. Schuetz. University Park Press, Baltimore.

Centola, G.M., Anderson, L. D. \& Channing, C. P. (1981) Oocyte maturation inhibition activity in porcine granulosa cells. Gamete Res. 4, 451-462.

Chang, M. C. (1955) The maturation of rabbit oocytes in culture and their maturation, activation, fertilization and subsequent development in Fallopian tube. $J$. exp. Zool. 128, 378-399.

Channing, C.P. \& Tsafriri, A. (1977) Mechanism of action of luteinizing hormone and follicle stimulating hormone in the ovary in vitro. Metabolism 26, 413-468.

Channing, C.P., Stone, S.L., Fowler, S., Edelson, S. \& Schwartz-Kripner, A. (1979) Comparison of porcine granulosa and cumulus cell properties: $\mathrm{LH} / \mathrm{hCG}$ receptors, ability to secrete progesterone and ability to respond to LH. Biol. Reprod. (Suppl) 20, 74A, Abstr. 125.

Cho, W.K., Stern, S. \& Biggers, J.D. (1974) Inhibitory effect of dibutyryl c-AMP on mouse oocyte maturation in vitro. J. exp. Zool. 187, 383-386.

Cuatrecasas, P., Hollenberg, M.D., Chang, K. \& Bennet, V. (1975) Hormone receptor complexes and their modulation of membrane function. Recent Prog. Horm. Res. 31, 37-94.

Dekel, N. \& Beers, W.H. (1978) Rat oocyte maturation in vitro: relief of cyclic AMP inhibition by gonadotropins. Proc. natn. Acad. Sci. U.S.A. 75, 43694373.

Dekel, N. \& Beers, W.H. (1980) Development of rat oocyte in vitro: inhibition and induction of maturation in the presence or absence of the cumulus oophorus. Devl Biol. 75, 247-252.

Dekel, N., Hillensjö, T. \& Kraicer, P.F. (1979) Maturational effects of gonadotrophins on the cumulus-oocyte complex of the rat. Biol. Reprod. 20, 191-197.

Dekel, N., Lawrence, T.S., Gilula, N.B. \& Beers, W.H. (1981) Modulation of cell-to-cell communication in the cumulus-oocyte complex and the regulation of oocyte maturation by LH. Devl Biol. 80, 356-362.

Donahue, R.P. (1972) The relation of oocyte maturation to ovulation in mammals. In Oogenesis, Ch. 22, pp. 413-438, Eds J. D. Biggers, \& A. W. Schuetz. University Park Press, Baltimore.

Foote, W. E. \& Thibault, C. (1969) Recherches experimentales sur la maturation in vitro des ovocytes de truie et de veau. Annls Biol. anim. Biochim. Biophys. 9, 329-349.

Gilula, N.B., Epstein, M.L. \& Beers, W.H. (1978) Cell-to-cell communication and ovulation; a study of the cumulus-oocyte complex. $J$. Cell Biol. 78, 58-75.
Gwatkin, R.B.L. \& Andersen, O.F. (1976) Hamster oocyte maturation in vitro: inhibition by follicular components. Life Sciences 19, 527-536.

Hillensjö, T. (1977) Dissociation of preovulatory maturational events in rat oocytes and cumuli in the presence of dibutyryl cAMP. Acta physiol. scand. 100, 261-263.

Hillensjö, T., Ekholm, C. \& Ahrén, K. (1978) Role of cyclic AMP in oocyte maturation and glycolysis in the preovulatory rat follicle. Acta endocr., Copenh. 87, 377-388.

Hillensjö, T., Kripner, A., Pomerantz, S.H. \& Channing, C.P. (1979) Action of porcine follicular fluid oocyte maturation inhibitor in vitro: Possible role of cumulus cells. In Ovarian Follicular and Corpus Luteum Function, pp. 283-290. Eds C. P. Channing, J. M. Marsh \& W. J. Sadler. Plenum Press, New York.

Hillensjö, T., Chari, S., Magnusson, C., Duame, E. \& Sturm, G. (1981) Inhibitory effects of low molecular weight fractions of human follicular fluid upon rat granulosa cells and oocytes in vitro. Excerpta Medica, in press.

Jagiello, G., Graffeo, J., Ducayen, M. \& Prosser, R. (1977) Further studies of inhibitors of in vitro, mammalian oocyte maturation. Fert. Steril. 28, 476-481.

Lawrence, T.S., Dekel, N. \& Beers, W.H. (1980) Binding of human chorionic gonadotropin by rat cumuli oophori and granulosa cells: A comparative study. Endocrinology 106, 1114-1118.

Leibfried, L. \& First, N.L. (1980a) Follicular control of meiosis in the porcine oocyte. Biol. Reprod. 23, $705-709$.

Leibfried, L. \& First, N.L. (1980b) Effect of bovine and porcine follicular fluid and granulosa cells on maturation of oocytes in vitro. Biol. Reprod. 23, 699-704.

Lindner, H.R., Tsafriri, A., Lieberman, M.E., Zor, U., Koch, Y., Bauminger, S. \& Barnea, A. (1974) Gonadotrophin action on cultured Graafian follicles: induction of maturation division of the mammalian oocyte and differentiation of the luteal cell. Recent Prog. Horm. Res. 30, 79-138.

Lindner, H.R., Bar-Ami, S. \& Tsafriri, A. (1980) Model systems for studying oocyte maturation. In Animal Models in Human Reproduction, pp. 65-85. Eds M. Serio \& L. Martini. Raven Press, New York.

Maller, J.L., Butcher, F.R. \& Krebs, E.G. (1979) Early effect of progesterone on levels of cyclic adenosine $3^{\prime}: 5^{\prime}$-monophosphate in Xenopus oocytes. J. biol. Chem. 254, 579-582.

Moor, R.M. \& Warnes, G.M. (1978) Regulation of oocyte maturation in mammals. In Control of Ovulation, pp. 159-176. Eds D. B. Crighton, G. R. Foxcroft, N. B. Haynes \& G. E. Lamming. Butterworths, London.

Moor, R.M., Smith, M.W. \& Dawson, R.M.C. (1980) Measurement of intercellular coupling between oocytes and cumulus cells using intracellular markers. Expl Cell Res. 126, 15-29.

Moor, R.M., Osborn, J.C., Cran, D.G. \& Walters, D.E. (1981) Selective effect of gonadotrophins on cell coupling, nuclear maturation and protein synthesis. in mammalian oocytes. J. Embryol. exp. Morph. 61, $347-365$. 
Morrill, G.A., Schatz, F. Kostellow, A.B. \& Poupko, J.M. (1977) Changes in cyclic AMP levels in the amphibian ovarian follicle following progesterone induction of meiotic maturation. Differentiation $\mathbf{8}$, 97-104.

Nekola, M.W. \& Moore-Smith, D.M. (1975) Failure of gonadotropins to induce in vitro maturation of mouse oocytes treated with dibutyryl cyclic AMP. $J$. Exp. Zool. 194, 529-534.

Paladino, G. (1890) I ponti intercellulari tra l'uovo ovarico e la cellule follicolari e la formogion della zona pellucida. Anat. Anz. 15, 254-259.

Pincus, G. \& Enzmann, E.V. (1935) The comparative behaviour of mammalian eggs in vivo and in vitro. $J$. exp. Med. 62, 655-675.

Sato, E. \& Ishibashi, T. (1977) Meiotic arresting action of the substance obtained from cell surface of porcine ovarian granulosa cells. Jap. J. Zootech. Sci. 48, 22-26.

Schorderet-Slatkine, S., Schorderet, M., Boquet, P., Godeau, F. \& Baulieu, E.E. (1978) Progesteroneinduced meiosis in Xenopus laevis oocytes: a role for cAMP at the "maturation-promoting factor" level. Cell 15, 1269-1275.

Schuetz, A.W. (1974) Role of hormones in oocyte maturation. Biol. Reprod. 10, 150-178.

Speaker, M.G. \& Butcher, F.R. (1977) Cyclic nucleotide fluctuations during steroid induced meiotic maturation of frog oocytes. Nature, Lond. 267, 848-859.

Stone, S. L., Pomerantz, S. H., Schwartz-Kripner, A. \& Channing, C. P. (1978) Inhibition of oocyte maturation from a porcine follicular fluid: further purification and evidence for reversible action. Biol. Reprod. 19, 585-592.

Tsafriri, A. (1978) Oocyte maturation in mammals. In The Vertebrate Ovary, pp. 409-442. Ed. R. E. Jones. Plenum Press, New York.

Tsafriri, A. (1979) Mammalian oocyte maturation: Model systems and their physiological relevance. In Ovarian Follicular and Corpus Luteum Function, pp. 269-281. Eds C. P. Channing, J. M. Marsh \& W. J. Sadler. Plenum Press, New York.

Tsafriri, A. \& Bar-Ami, S. (1981) Oocyte maturation inhibitor: a 1981 perspective. In Intra-Ovarian
Control Mechanisms, Eds C. PO. Channing \& S. J. Segal. Plenum press, New York. (In press).

Tsafriri, A. \& Channing, C.P. (1975) An inhibitory influence of granulosa cells and follicular fluid upon porcine oocyte meiosis in vitro. Endocrinology 96, 922-927.

Tsafriri, A., Lindner, H. R., Zor, U. \& Lamprecht, S. A. (1972) In vitro induction of meiotic division in follicle-enclosed rat oocytes by LH, cyclic AMP and prostaglandin $\mathrm{E}_{2} . J$. Reprod. Fert. 31, 39-50.

Tsafriri, A., Lieberman, M. E., Koch, Y., Bauminger, S., Chobsieng, P., Zor, U. \& Lindner, H.R. (1976a) Capacity of immunologically purified FSH to stimulate cyclic AMP accumulation and steroidogenesis in Graafian follicles and to induce ovum maturation and ovulation in the rat. Endocrinology 98, 655661.

Tsafriri, A., Pomerantz, S.H. \& Channing, C.P. (1976b) Follicular control of oocyte maturation. In Ovulation in the Human, Vol. 8, pp. 31-39. Eds P. G. Crosignani \& D. R. Mishel. Academic Press, New York.

Tsafriri, A., Pomerantz, S.H. \& Channing, C.P. (1976c) Inhibition of oocyte maturation by porcine follicular fluid: partial characterization of the inhibitor. Biol. Reprod. 14, 511-516.

Tsafriri, A., Channing, C.P., Pomerantz, S.H. \& Lindner, H.R. (1977) Inhibition of maturation of isolated rat oocytes by porcine follicular fluid. J. Endocr. 75, 285-291.

Tsafriri, A., Weinstein, Y., Bar-Ami, S., Channing, C.P., Pomerantz, S.H. \& Lindner, H.R. (1979) The control of meiotic maturation of the rat oocyte. In Research on Steroids, Vol. 8, pp. 193-198. Ed. E. Conti. Academic Press, London.

Udenfriend, S., Stein, S., Bohlen, P., Dairman, W., Leimgruber, W. \& Weigle, M. (1972) Fluorescamine: a reagent for assay of aminoacids, peptides, proteins and primary amines in the picomole range. Science, N.Y. 178, 871-872.

Vermeiden, J. P.W. \& Zeilmaker, G.M. (1974) Relationship between maturation division, ovulation and luteinization in the female rat. Endocrinology 95, $341-351$. 